Камінська Ольга

доктор психологічних наук, професор, професор кафедри загальної психології та психодіагностики Рівненського державного гуманітарного університету http://orcid.org/0000-0002-4954-7811 DOI https://doi.org/10.35619/prap_rv.vi14.154

\title{
ОСОБИСТІСНІ ДЕТЕРМІНАНТИ КОНФЛІКТНОСТІ В ПІДЛІТКОВОМУ ВІЦІ
}

Анотація. Метою роботи є виявлення особистісних детермінант конфліктності в підлітковому віці. Постановка мети зумовлена актуальністю проблеми високої конфліктності в підлітковому віці, щзо вимагає здійснення подальших досліджень, завданням яких є аналіз чинників, щзо зумовлюють формування високої конфліктності та розробка рекомендацій щзодо вироблення особистістю конструктивних форм поведінки в конфліктній ситуації. При проведені емпіричного дослідження було використано методику діагностики рівня конфліктності особистості (Ложкін, Пов'якель) та шістнадиятифакторний особистісний опитувальник Кеттелла. Встановлено, що особистісними детермінантами високої конфліктності $\epsilon$ напруженість, низький самоконтроль, емоційна нестабільність, низька нормативність поведінки, підозрілість. Середній рівень конфліктності супроводжується домінуванням таких характеристик як сміливість, прямолінійність, нонконформізм. Разом з иим респондентів з низькою конфліктністю переважають такі риси як підпорядкованість, висока нормативність поведінки, несміливість, конформізм. При виникненні високої конфліктності, щзо супроводжується деструктивними формами побудови взаємодї з оточуючими, провідним особистісним фактором є низька нормативність поведінки, щзо призводить до демонстрації індивідом жорстокості щодо інших.

Ключові слова: конфліктність, жорстокість, булінг, низька нормативність поведінки, деструктивні форми поведінки.

Постановка проблеми. У сучасному соціумі спостерігається тенденція до поширення в підлітковому середовищі девіантних та делінквентних форм поведінки, в основі яких лежить висока агресивність та конфліктність особистості. Враховуючи це важливим завданням, що постає сьогодні перед психологами та представниками суміжних галузей, є дослідження чинників, що зумовлюють формування високої конфліктності, зокрема особистісних її детермінант. Це в свою чергу дозволить розробити систему ефективних засобів профілактики та корекції підвищеної конфліктності підлітків та запобігти закріпленню цієї характеристики в структурі особистості що формується.

Аналіз останніх досліджень 3 проблеми. Конфлікт (від лат. confliktus - зіткнення) протистояння на індивідуально-психологічному або соціально-психологічному рівнях значущих, конкурентних або несумісних потреб, мотивів, інтересів, цілей, дій і вчинків, коли одна із сторін сприймає дії іншої як загрозу іiї інтересам (Дондюк, 2002).

Підлітковий вік - це період біологічної перебудови організму, що супроводжується змінами особистості, які проявляються у підвищенні рівня агресивності, конфліктності, загостренні відносин з найближчим оточенням: друзями, однокласниками, батьками і вчителями (Щербакова, Клиженко, 2019). Між підлітками можуть виникати такі типи конфліктів: міжособистісні, конфлікт між особистістю i групою, міжгрупові: протиборство учасників відбувається безпосередньо, тут і тепер, на основі зіткнення їх особистих мотивів. У міжособистісних конфліктах підлітків виявляється весь спектр причин: загальних i часткових, об'єктивних i суб'єктивних (Bochaver, Zhilinskaya \& Khlomov, 2015). Міжособистісні конфлікти підлітків є своєрідним «полігоном» перевірки характерів, темпераментів, прояву здібностей, інтелекту, волі та інших індивідуально-психологічних особливостей. Такі конфлікти відрізняються високою емоційністю і охопленням майже всіх сторін стосунків між конфліктуючими суб'єктами (Скутина, 2004). 
Суперечливість прагнень підліткового віку належати до референтної групи однолітків і бути як усі, а також виділитися, самоствердитися, призводить до виникнення конфліктів між підлітком і групою. Такі конфлікти мають такі особливості: конфліктна взаємодія відбувається на основі зіткнення особистих і групових мотивів; причини конфлікту безпосередньо пов'язані 3 положенням підлітка у групі, яке характеризується такими поняттями як позиція, статус, роль (Яновська \& Калюжна, 2016). За даними Токаревої (2019) поведінкові стратегії особистості формуються упродовж життя і є результатом взаємодії вимірів соціокультурного середовища, особистісних чинників та активності самої людини. Значущість цих чинників на різних етапах онтогенезу змінюється. У підлітковому віці особистісне становлення відбувається переважно у контекстуальному профілі генези персонологічних конструктів. Баришнікова (2017) стверджує, що міжособистісна взаємодія в конфліктних ситуаціях у підлітків є важкою, у їхніх стосунках домінують деструктивні тенденції. Часто замість аналізу проблеми та пошуку кращих способів вирішення підліток намагається в інтенсивний спосіб вплинути на об'єкт протиріччя і здійснює дії, що призводять до ескалації конфлікту. Це пов'язано в першу чергу з недостатньо розвинутими комунікативною і соціальною компетентністю. Конфліктність підлітка призводить до недовіри до нього, ворожості, а згодом і до закріплення в його свідомості стереотипів конфліктної поведінки. Набутий підлітком досвід успішного або невдалого спілкування служить основою для засвоєння різних за конструктивністю способів вирішення конфліктних ситуацій. Конструктивне вирішення конфлікту можливо, якщо між сторонами відбувається діалог, в ході якого вони висловлюють один одному свої претензії та приймають спільне рішення про врегулювання ситуації, і як зробити так, щоб вона не повторювалася (Баришнікова, 2017). За даними Резнікової та Солодкої (2018) на стиль поведінки в конфліктній ситуації впливають особливості самосвідомості підлітків. Підлітки із домінуючим типом міжособистісних відносин та високою самооцінкою в конфлікті обирають стиль суперництва, а підлітки з дружнім типом та середньою самооцінкою обирають стиль пристосування. Яновська \& Калюжна (2016) стверджують, що підлітки 3 низьким рівнем конфліктності обирають такі стратегії реагування у конфлікті як уникнення та поступливість, тобто вони або намагаються уникати вирішення конфліктних ситуацій, що склались, або ж прагнуть вийти 3 конфлікту шляхом ігнорування власних інтересів та поступок іншій стороні. Підлітки з середнім рівнем конфліктності демонструють різні способи поведінки у конфліктних ситуаціях від уникнення до суперництва, від співробітництва до пристосування. Але найбільш типовим для них $є$ стиль компромісу, тобто намагання частково задовольнити як свої інтереси, так i інтереси іншого. Для підлітків з високим рівнем конфліктності притаманним $є$ стиль суперництва у конфлікті, тобто вони здійснюють активні дії для задоволення власних потреб і досягнення перемоги у ситуації, що склалася.

Незважаючи на значну кількість публікацій, що стосуються проблеми високої конфліктності в підлітковому віці, психологічні детермінанти, що зумовлюють формування цієї характеристики, в сучасній науці вивчені недостатньо.

Мета статті - виявити особистісні детермінанти конфліктності в підлітковому віці.

Виклад основного матеріалу. Емпіричне дослідження охопило 80 осіб віком від 14 до 15 років. Було використано методику діагностики рівня конфліктності особистості (авт. Ложкін, Пов'якель) та шістнадцятифакторний особистісний опитувальник Кеттелла 3 метою виявлення взаємозв'язку рівня конфліктності та домінуючими особистісними характеристиками підлітків.

За методикою «Діагностика рівня конфліктності особистості» (авт. Ложкін, Пов'якель) встановлено, що 22,7\% опитаних підлітків мають низький рівень конфліктності, $59 \%$ - середній та 18,3\% - високий. Підлітки з низьким рівнем конфліктності не схильні до демонстрації агресивних моделей поведінки, включаючи як вербальну, так і фізичну агресію, частіше йдуть на компроміс та намагаються досягнути взаєморозуміння при спілкуванні з партнером, при цьому іноді навіть нехтуючи власними інтересами. У конфліктній ситуації вони почуваються дискомфортно, прагнуть іiі уникнути, або ж швидше з неї вийти. Вони характеризуються достатньою емоційною стійкістю та низькою імпульсивністю, що дозволяє зберігати самоконтроль в конфліктній ситуації та перешкоджає емоційному зараженню від агресивно налаштованого партнера по спілкуванню.

Особи, яким властивий середній рівень конфліктності, рідко виступають ініціаторами конфлікту, однак схильні відстоювати свої інтереси, якщо конфлікт вже зав'язався. Вони готові 
демонструвати власну позицію, навіть якщо вона буде негативно сприйнята опонентом, та це призведе до загострення конфліктної ситуації. Такі респонденти готові прийти до компромісу у випадку, якщо інша сторона також піде на поступки. Підлітки, яким притаманна висока конфліктність, демонструють ворожі та агресивні тенденції при взаємодії з опонентом, використовують різні форми тиску та часто намагаються самоствердитись за рахунок інших. Найчастіше вони самі ініціюють конфлікт, демонструють схильність до маніпуляцій, не готові йти на компроміс та вирішувати суперечку конструктивними способами. При цьому конфліктність часто проявляється при взаємодії з дорослими (батьками, вчителями, найближчим оточенням), демонструється негативізм, неприйняття правил та заборон, відторгнення соціальних стандартів, що сприймаються як нав'язані суспільством. Також деструктивні форми поведінки можуть проявлятися стосовно однолітків, що не входять в референтну для особистості групу. В цьому випадку часто спостерігаються прояви булінгу та цькування інших дітей, в основі яких лежить прагнення самоствердитись за рахунок приниження іншого.

При проведенні подальшого дослідження ми використали шістнадцятифакторний особистісний опитувальник Кеттелла 3 метою виявлення домінуючих характеристик, що притаманні представникам кожної з виділених нами категорій. На основі узагальнення отриманих даних побудовано психологічний профіль особистості 3 високим рівнем конфліктності, представлений на рис. 1.

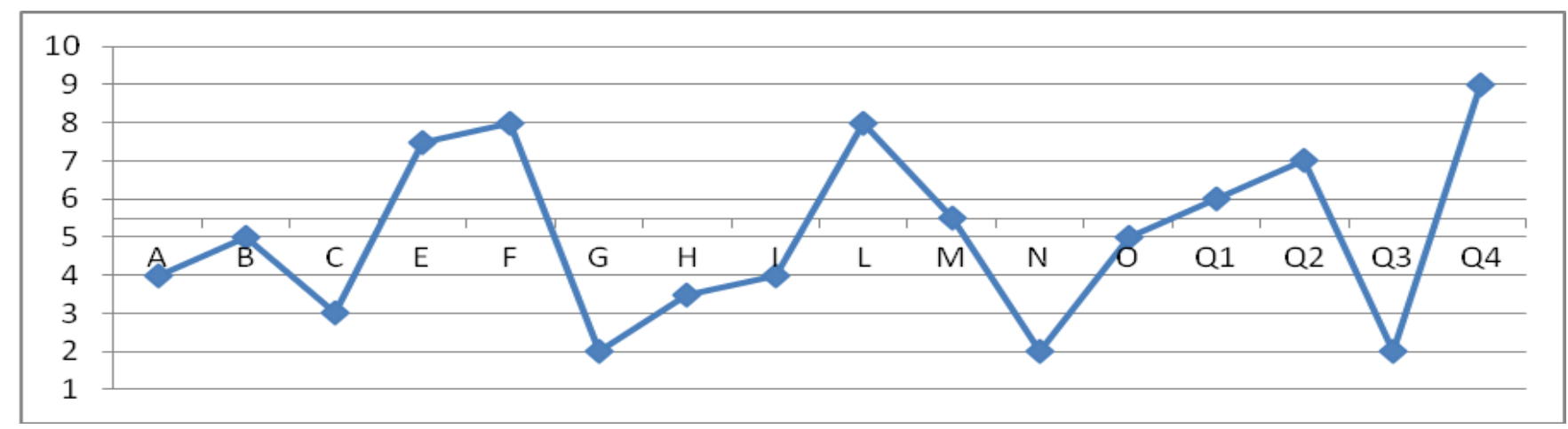

\section{Рис. 1. Профіль конфліктної особистості}

Примітки: А - замкнутість (-), комунікабельність (+); В - конкретне мислення (-), абстрактне мислення (+); С емоційна нестабільність (-), емоційна стабільність (+); Е - підпорядкованість (-), домінантність (+); F - стриманість (-), експресивність (+); G - (низька нормативність поведінки (-), висока нормативність поведінки (+); Н - несміливість (-), сміливість (+); I - жорсткість (-), чутливість (+); L - довірливість (-), підозрілість (+); M - практичність (-), мрійливість $(+)$; N - прямолінійність (-), дипломатичність (+); О - спокій (-), тривожність (+); Q1 - консерватизм (-), радикалізм $(+)$; Q2 - конформізм (-), нонконформізм (+); Q3 - низький самоконтроль (-), високий самоконтроль (+); Q4 розслабленість (-), напруженість $(+)$.

Аналіз профілю дозволив визначити, що конфліктній особистості найбільшою мірою притаманні такі характеристики, як напруженість, низький самоконтроль, емоційна нестабільність, низька нормативність поведінки, підозрілість. Також важливу роль відіграють такі риси, як домінантність, експресивність, прямолінійність, нонконформізм. Меншої ваги набули такі характеристики, як сміливість та жорстокість.

Отже, конфліктна особистість, з одного боку, володіє характеристиками, які дозволяють їй відстоювати власну позицію, не піддаватись тиску групи, захищати свої інтереси, бути лідером (сміливість, домінантність, нонконформізм, прямолінійність), а 3 іншого - схильна до прояву деструктивних поведінкових тенденцій (низька нормативність поведінки, жорстокість).

У процесі дослідження побудовано також профіль особистості з середнім рівнем конфліктності (рис. 2). 


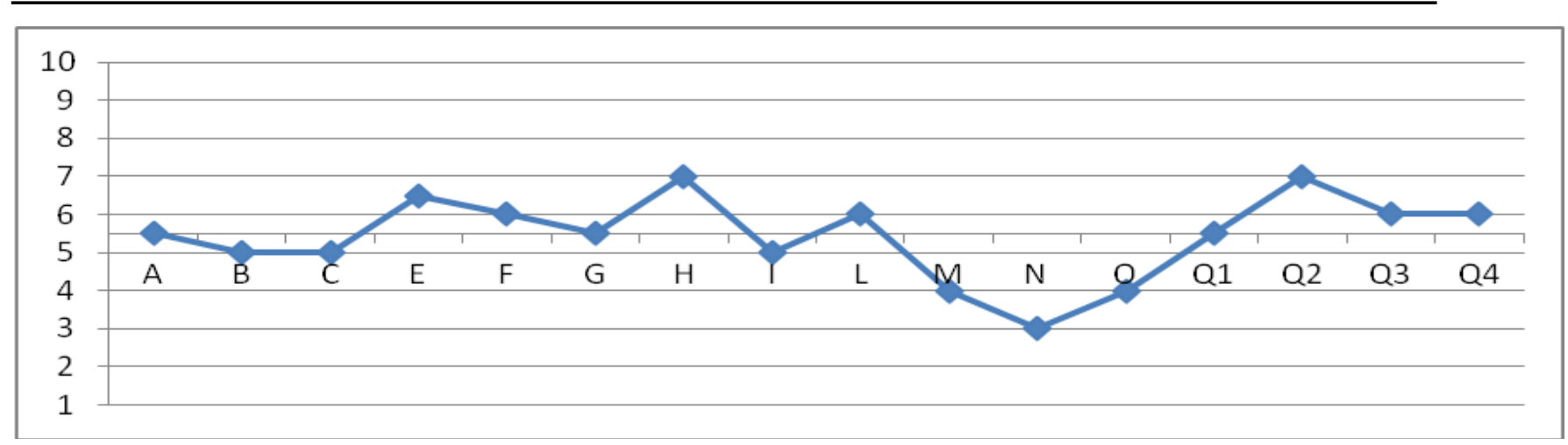

Примітка: див. рис. 1.

\section{Рис. 2. Профіль особистості з середнім рівнем конфліктності}

У цьому профілі на передній план виходять такі характеристики, як сміливість, прямолінійність, нонконформізм. Значної ваги набувають такі риси як спокій та високий самоконтроль.

Порівняння профілю конфліктної особистості та особистості із середнім рівнем конфліктності вказує на те, що в першому випадку домінуючої рисою є низька нормативність поведінки, що і зумовлює тенденцію до прояву жорстокості щодо інших. Також цим респондентам притаманна емоційна нестабільність, що ускладнює процеси саморегуляції та зумовлює прояв імпульсивних форм поведінки, коли особистість не встигає оцінити можливі наслідки своїх дій. Надмірна підозрілість також створює основу для деструктивних способів реагування через недовіру до оточуючих. Натомість особистість із середнім рівнем конфліктності має кращу здатність до самоконтролю та здатна регулювати власну поведінку відповідно до норм та соціальних стандартів, що створює основу для побудови конструктивних форм взаємодії 3 оточуючими.

У процесі дослідження розроблено також профіль особистості з низькою конфліктністю (рис. 3).

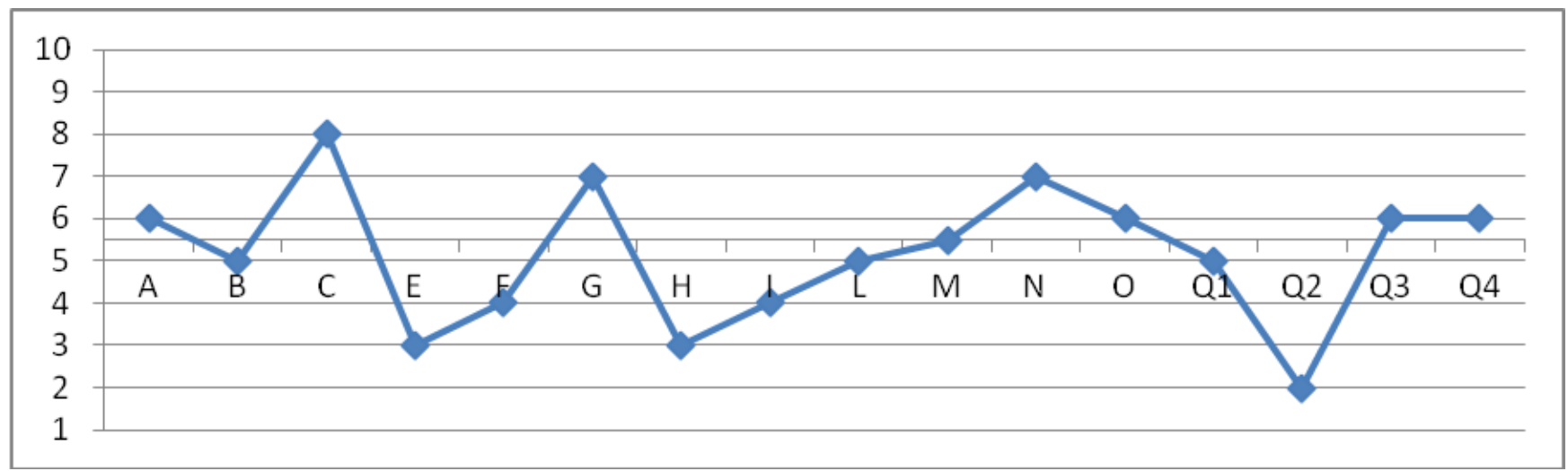

Примітка: див. рис. 1.

Рис. 3. Профіль особистості з низьким рівнем конфліктності

Аналіз отриманих даних вказує на домінування в особистості таких рис як підпорядкованість, висока нормативність поведінки, несміливість, конформізм. Достатньо вираженими також $є$ такі риси: чутливість, дипломатичність, тривожність. Респондентам із низькою конфліктністю важко відстоювати власну позицію та боротись за свої інтереси (несміливість), а також йти проти групи, висловлюючи свою думку чи пропонуючи альтернативний спосіб дій (конформізм). Схильність до підпорядкованості не дозволяє особистості брати на себе роль лідера та демонструвати високу соціальну активність. Чутливість та тривожність змушують таких респондентів сприймати конфліктну ситуацію як загрозливу та уникати її будь-якими шляхами. 
Висновки і перспективи подалыших розвідок. Ступінь вираженості конфліктності залежить від системи особистісних змінних. Емпіричним шляхом встановлено, що особистісними детермінантами високої конфліктності $\epsilon$ напруженість, низький самоконтроль, емоційна нестабільність, низька нормативність поведінки, підозрілість. Середній рівень конфліктності супроводжується домінуванням таких характеристик як сміливість, прямолінійність, нонконформізм. Разом $з$ цим в респондентів із низькою конфліктністю переважають такі риси як підпорядкованість, висока нормативність поведінки, несміливість, конформізм.

Враховуючи це, ми вважаємо, що при виникненні високої конфліктності, що супроводжується деструктивними формами побудови взаємодії 3 оточуючими, провідним особистісним фактором $є$ низька нормативність поведінки, що призводить до демонстрації індивідом жорстокості щодо інших. Робота психолога при цьому повинна бути скерована на подолання недоліків процесу соціалізації, за рахунок яких особистість не змогла засвоїти соціальні норми та цінності, а також на формування світобачення, основаного на гуманістичних засадах. При цьому доречним $є$ використання технік когнітивно-біхевіоральної терапії, гуманістичноорієнтованого підходу, як індивідуальних, так і групових форм роботи.

Перспективним напрямком дослідження є розробка корекційно-розвивальної програми, спрямованої на подолання деструктивних тенденцій в ситуації конфліктної взаємодії.

\section{СПИСОК ПОСИЛАНЬ}

Баришнікова, О. Є. (2017). Формування готовності підлітків до конструктивної поведінки в конфлікті. Організаційно-управлінські та психологічні аспекти сучасного ринку прачі України (с. 19-25). Київ: ІПК ДСЗУ.

Дондюк, А. (2002). Конфлікт. Філософський енциклопедичний словник. Київ: Абрис.

Резнікова, О. А., \& Солодка, О. В. (2018). Психологічні особливості поведінки підлітків в конфліктних ситуаціях. Теорія і практика сучасної психологї, 2, 168-172.

Скутина, Т. В. (2004). Конфликт как механизм развития отношений с близким сверстником в подростковом возрасте. Психология и школа, 3, 92-105.

Токарева, Н. (2019). Психологічний контент конфліктної поведінки підлітків. Проблеми сучасної психології, 45, 381-404.

Щербакова, О. О., \& Клиженко, Я. В. (2019). Корекційно-розвивальна програма «Конфлікт крізь призму підліткового віку». Теорія і практика сучасної психологї, 4, 2, 100-104.

Яновська, Т. А., \& Калюжна, Ю. І. (2016). Психологічні основи профілактики конфліктів у роботі соціального працівника з підлітками. Проблеми сучасної психологї, 31, 583-594.

Bochaver, A. A., Zhilinskaya, A. V., \& Khlomov, K. D. (2015). School Bullying and Teachers' Attitudes. Social Psychology \& Society, 6, 1, 100-113.

\section{REFERENCES}

Baryshnikova, O. Ie. (2017). Formuvannia hotovnosti pidlitkiv do konstruktyvnoi povedinky v konflikti [Formation of teenagers' readiness for constructive behavior in conflict]. Orhanizatsiinoupravlinski ta psykholohichni aspekty suchasnoho rynku pratsi Ukrainy (s. 19-25). Kyiv: IPK DSZU. [in Ukrainian].

Dondiuk, A. (2002). Konflikt [Conflict]. Filosofskyi entsyklopedychnyi slovnyk. Kyiv: Abrys. [in Ukrainian].

Reznikova, O. A., \& Solodka, O. V. (2018). Psykholohichni osoblyvosti povedinky pidlitkiv v konfliktnykh sytuatsiiakh [Psychological features of adolescent behavior in conflict situations]. Teoriia i praktyka suchasnoi psykholohii, 2, 168-172. [in Ukrainian].

Skutyna, T. V. (2004). Konflykt kak mekhanyzm razvytyia otnoshenyi s blyzkym sverstnykom v podrostkovom vozraste [Conflict as a mechanism for developing relationships with close peers in adolescence]. Psykholohyia y shkola, 3, 92-105. [in Russia].

Tokareva, N. (2019). Psykholohichnyi kontent konfliktnoi povedinky pidlitkiv [Psychological content of adolescent conflict behavior]. Problemy suchasnoi psykholohii, 45, 381-404. [in Ukrainian]. 
Shcherbakova, O. O., \& Klyzhenko, Ya. V. (2019). Korektsiino-rozvyvalna prohrama «Konflikt kriz pryzmu pidlitkovoho viku» [Correction and Development Program «Conflict through the Prism of Adolescence»]. Teoriia i praktyka suchasnoi psykholohii, 4, 2, 100-104. [in Ukrainian].

Yanovska, T. A., \& Kaliuzhna, Yu. I. (2016). Psykholohichni osnovy profilaktyky konfliktiv u roboti sotsialnoho pratsivnyka z pidlitkamy [Psychological bases of conflict prevention in work of social worker with teenagers]. Problemy suchasnoi psykholohii, 31, 583-594. [in Ukrainian].

Bochaver, A. A., Zhilinskaya, A. V., \& Khlomov, K. D. (2015). School Bullying and Teachers' Attitudes. Social Psychology \& Society, 6, 1, 100-113. [in English].

\title{
PERSONAL DETERMINANTS OF CONFLICT IN THE ADOLESCENT AGE
}

\author{
Kaminska Olga \\ Doctor of Psychology, Professor, \\ Professor of the Department of General Psychology and Psychodiagnostics, \\ Rivne State University of the Humanities \\ http://orcid.org/0000-0002-4954-7811 \\ DOI https://doi.org/10.35619/prap_rv.vi14.154
}

\begin{abstract}
The purpose of the work is to identify the personal determinants of conflict in adolescence. The empirical study used the methodology for diagnosing the level of personality conflict (G.V. Lozhkin, N.I. Povyakel) and sixteen-factor personal questionnaire RB Kettell. It is established that the conflict personality is most characteristic of such characteristics as tension, low self-control, emotional instability, low normative behavior, suspicion. Features such as dominance, expressiveness, straightforwardness, non-conformism also play an important role. Characteristics such as courage and cruelty have gained less weight. In the profile of a person with average level of conflict, such characteristics as courage, straightforwardness, non-conformism come to the fore. Features such as peace and high self-control are of great importance. The analysis of the profile of a person with a low level of conflict indicates the dominance of such features as subordination, high normative behavior, timidity, conformism. The following features are also quite pronounced: sensitivity, diplomacy, anxiety. Generalization of theoretical propositions and empirical data allows us to consider conflict as a personal trait, which manifests itself in the emergence of contradictions between individuals or groups of people and involves the use of destructive or constructive behaviors against the opponent. The degree of severity of conflict depends on other personal characteristics. Empirically, it has been established that the personal determinants of high conflict are tension, low self-control, emotional instability, low normative behavior, suspicion. The average level of conflict is accompanied by the dominance of such characteristics as courage, straightforwardness, non-conformism. At the same time, respondents with low conflict are dominated by such traits as subordination, high normative behavior, timidity, conformism. In the event of high conflict, accompanied by destructive forms of interaction with others, the leading personal factor is a low normative behavior, which leads to the demonstration of cruelty to others. When conducting psychocorrection, it is appropriate to use techniques of cognitive-behavioral therapy, humanistic oriented approach, both individual and group forms of work.
\end{abstract}

Key words: conflict, cruelty, bullying, low normative behavior, destructive behaviors. 